\title{
Evaluation of Some Sunflower Genotypes under Drought Condition in Newly Reclaimed Sandy Soil
}

\author{
A.H. Salem, A.E.A. Omar and M.M.A. Ali \\ Agronomy Department, Faculty of Agriculture, Zagazig \\ University, Sharkia, Egypt.
}

\begin{abstract}
W ATER stress is one of the severe limitations of crop growth especially in arid and semi-arid regions of the world as it has a vital role in plant growth and development at all growth stages. The aim of the present study is to evaluate the response of twelve sunflower genotypes to three levels of water supply to identify the more suitable one for drought condition. Two field experiments were conducted to evaluate twelve diverse sunflower genotypes grown under adequate $\left(3000 \mathrm{~m}^{3}\right)$, moderate $\left(2000 \mathrm{~m}^{3}\right)$ and severe $\left(1000 \mathrm{~m}^{3}\right)$ water regime for chlorophyll index, transpiration rate, leaf water content, plant height, head diameter, seeds/head, 1000-seed weight, seed and oil yield. Moderate and severe water regimes had a significant impact on transpiration rate, leaf water content, yield contributing characters and oil yield of all sunflower genotypes. However sunflower genotypes showed different response to the different water regimes. The highest seed and oil yields were attained in L990 and Giza 102 under adequate water supply, while L38 was the best under moderate and severe water regime. On the basis of the obtained results, sunflower genotype L990 could be recommended to grow under adequate water supply, while L38 for the moderate and severe water regimes.
\end{abstract}

Keywords: Helianthus annuus, Drought, Drip irrigation, Physiological characters, Seed and oil yield, Water deficit.

Abbreviations: Fed. $=$ Feddan $=4200 \mathrm{~m}^{2}$

Sunflower (Helianthus annuus, L.) is one of the most important oil seed crop of the world as well as in Egypt. It can be cultivated successfully under newly reclaimed sandy soil conditions. Since, Egypt is located in a dry region there is no enough water resources for summer crops irrigation especially under sandy reclaimed soils.

Both quantity and distribution of water has a significant impact on seed and oil yields in sunflower (Esmail, 2000; Reddy et al., 2003 and Iqbal et al., 2005). Intensity of yield reduction by drought stress depends on the growth stage of a crop, the severity of the drought and tolerance of genotype (Lorens et al., 1987). Water stress during the yield formation period reduced yield when compared to

Emails : zasalem@yahoo.com; omaromarI971@yahoo.com and abd_lhamed @ yahoo. com 
full irrigation, but the reduction was much less than when stress occurred during flowering period (Kazi et al., 2002; Rauf, 2008 and Asbagh et al., 2009). Nezami et al. (2008) indicated that drought stress decreased plant height, stem diameter, head size, seed number/head, 100-seed weight, seed weight/head and SPAD readings as compared to control (without stress). Alahdadi et al. (2011) reported that the drought stress decreased significantly head diameter, seeds number / head, 1000-seed weight, seed oil content and seed yield. Similarly, Mojaddam et al. (2011) noticed that seed yield of sunflower and its components were reduced significantly in response to increasing drought severity.

The performance of local and introduced genetic materials in Pakistan were evaluated for yield, yield components and physiological traits under drought conditions (Rauf \& Sadaqat, 2007; Rauf \& Sadaqat, 2008 and Rauf et al., 2008). Many investigators evaluated some local and introduced genotypes under Egyptian conditions. Varietal differences were reported in most growth and yield attributes (Sarhan, 1995; Abo Khadra et al., 2002 and Sharief et al., 2003). Abdel-Wahab et al. (2005) evaluated three sunflower hybrids (Euroflour, XF4731 and Vidoc). They reported that, XF4731 hybrid surpassed the other hybrids in seed yield/fed and oil yield/fed. Also Acko (2008) recorded significant differences among sunflower hybrids in yield and its attributes. Yasein (2010) tested two sunflower cultivars (Sakha 53 and Giza 102) under sandy soil conditions and indicated that Sakha 53 surpassed Giza 102 in plant height, head diameter, number of seed/head, seed weight/head, seed yield/fed and seed oil content. The present study was undertaken to find out the response of sunflower genotypes to water regimes under sandy soil condition.

\section{Materials and Methods}

Two field experiments were conducted at the Agricultural Research Station, Faculty of Agriculture, Zagazig University at El-Khattara, Sharkia Governorate, Egypt during the two successive seasons 2009 and 2010. The study aimed to investigate the response of sunflower genotypes to different water regimes under drip irrigation system. The soil of the experimental site is sandy in texture where it has a particle size distribution of $89.2,6.6$ and $4.2 \%$ for sand, silt and clay, respectively. The soil had an average $\mathrm{pH}$ of 8.1 and organic matter content of $0.26 \%$. The average available N, P and K contents were 15.1, 3.2 and $90.5 \mathrm{ppm}$, respectively. Twelve sunflower genotypes (six local i.e. L38, L20, L11, L8, Giza 102 and Sakha 53 as well as six imported i.e. L19, L235, L350, L990, L770 and L460 from Bulgaria) were evaluated under three levels of water regime (control supplemented by $3000 \mathrm{~m}^{3}$, moderate drought "2000 $\mathrm{m}^{3 /}$ and severe drought $" 1000 \mathrm{~m}^{3}$ ). Irrigation water was adjusted by a water counter for all irrigation treatments. A split plot design with four replications was used, where the main plots assigned to water regimes, and the subplots for sunflower genotypes. The subplots area $\left(17.5 \mathrm{~m}^{2}\right)$ included 7 rows of $5 \mathrm{~m}$ length and $50 \mathrm{~cm}$ apart. The two outer rows were left as borders. The next two outer rows were devoted for determination of physiological characters and yield attributes. The three central rows were devoted for final yield determination. Three seeds of sunflower were Egypt. J. Agron . 34, No.2 (2012) 
sown in hills $30 \mathrm{~cm}$ apart on $1^{\text {st }}$ June in both seasons. After 21 days from sowing, thinning to one plant/hill was done, giving a planting density of 28000 plant/fed. Tomato was the preceding crop in both seasons. Nitrogen was applied as ammonium sulphate $(20.6 \% \mathrm{~N})$ at a rate of $90 \mathrm{~kg} \mathrm{~N} / \mathrm{fed}$ in four equal doses, after thinning at 7 days interval.

Calcium superphosphate $\left(15.5 \% \mathrm{P}_{2} \mathrm{O}_{5}\right)$ was added at a rate of $31 \mathrm{~kg} \mathrm{P}_{2} \mathrm{O}_{5} /$ fed at seed bed preparation. Potassium sulphate was applied at a rate of $48 \mathrm{~kg}$ $\mathrm{K}_{2} \mathrm{O} /$ fed in two equal splits, the first at sowing and the second after thinning. All other cultural practices for growing sunflower in sandy soil were applied.

At flowering, five plants were randomly labeled in each subplot to estimate the following physiological characters: chlorophyll content, transpiration rate and leaf water content. Leaf Chlorophyll content was assessed using chlorophyll meter (SPAD-502, Minolta), measurements being taken at three points of each leaf (upper, middle and lower part). The Average of these three readings was considered as SPAD reading of the leaf. Leaf transpiration rate $\left(\mathrm{mg} \mathrm{H}_{2} \mathrm{O} / \mathrm{cm}^{2} / \mathrm{hr}\right)$ was estimated according to the adopted rapid weighing systems (Migahid \& Amer, 1952 and Gosev, 1960). Leaf water content (\%) was determined according to Turner (1981).

At harvest five guarded plants from the specified rows were taken where the following yield attributes were recorded: Plant height and head diameter were measured in $\mathrm{cm}$. Number of seeds per head was counted as average of five plants. A sample of 1000-filled seeds (at $8 \%$ moisture content) was drawn at random from the bulked seeds of five plants and weighed in $(\mathrm{g})$.

Seed yield (ton/fed) was recorded at harvest from the three central rows. Seed yield /fed adjusted at $8 \%$ moisture content. Oil content was determined according to A.O.A.C. (1984) using Soxhlet apparatus and diethyl ether as a solvent. Oil yield $(\mathrm{kg} / \mathrm{fed})$ was calculated by multiplying seed yield $(\mathrm{kg} / \mathrm{fed}) \mathrm{x}$ seed oil content $(\%)$.

Analysis of variance and combined analysis for the two seasons were carried out as described by Steel \& Torrie (1980). For comparison between means, Duncan's multiple range test was applied (Duncan, 1955). In interaction tables, capital and small letters were used to compare rows and columns means, respectively.

\section{Results}

\section{Physiological characters}

Effect of water regime levels

Results in Table 1 revealed that severe drought treatment $\left(1000 \mathrm{~m}^{3} / \mathrm{fed}\right)$ caused a significant reduction in leaf chlorophyll value (in the $1^{\text {st }}$ season only). Meanwhile, results of both seasons and their combined analysis exhibited a significant decrease in transpiration rate and leaf water content with each reduction in the level of water regime. 


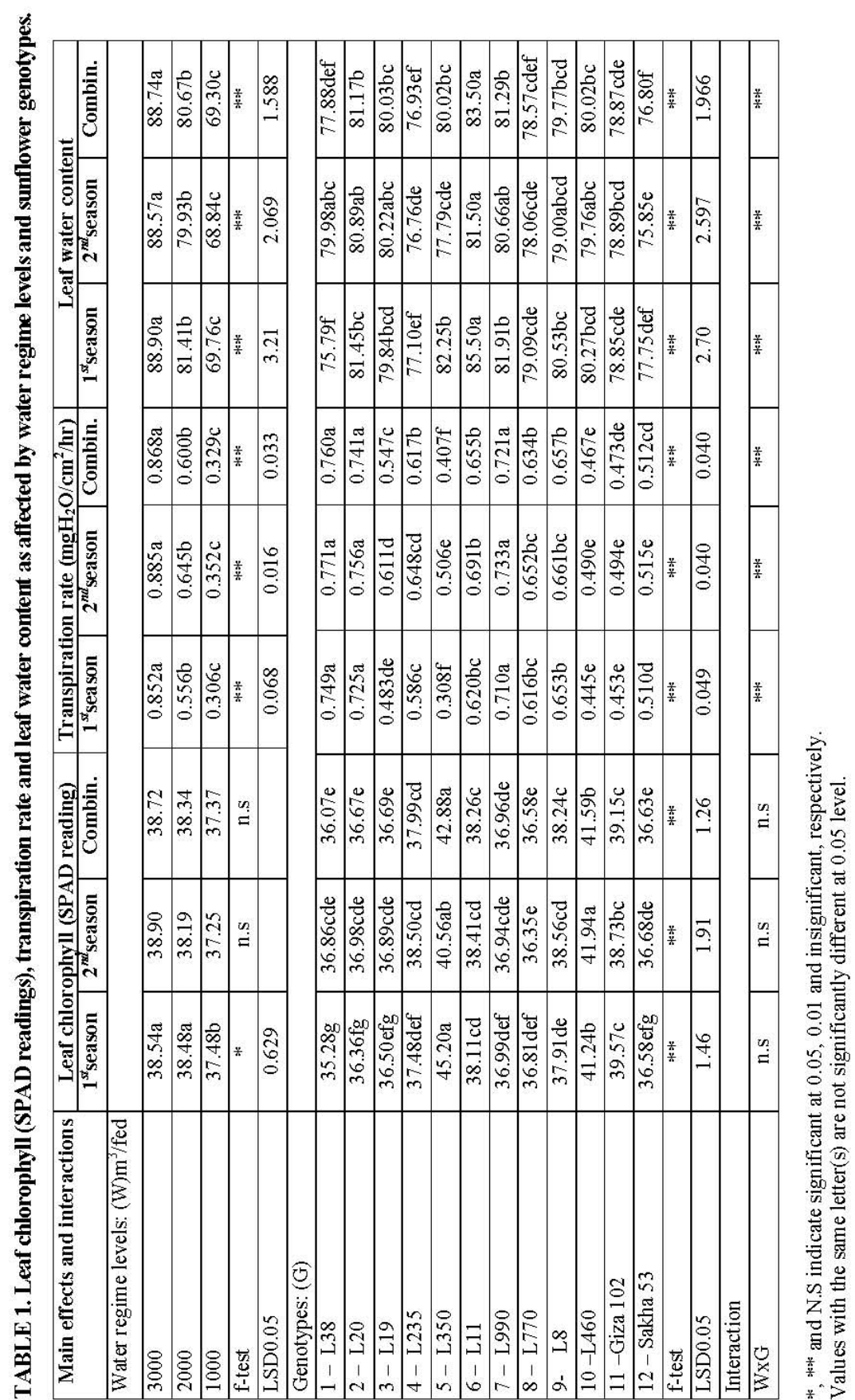

Egypt. J. Agron . 34, No.2 (2012) 


\section{Genotypes differences}

Results of both seasons and their combined analysis presented in Table 1 pointed out highly significant differences among the tested genotypes in each leaf chlorophyll value, transpiration rate and leaf water content. As obvious from the combined analysis, it is evident that L350 had the highest leaf chlorophyll value followed by L460, while, L38, L20, L19, L990, L770 and Sakha 53 were similar in having lower values of leaf chlorophyll content. Sunflower genotype L38, L20 and L990 exhibited the highest transpiration rate followed by each of L235, L11, L770 and L8 then L19. Whereas, L350 recorded the lowest transpiration rate value. In addition, L11 genotype recorded the highest leaf water content followed by each of L20, L990, L350, L8 and L460 on par. But, L20 and L990 attained higher leaf water content than the rest tested genotypes.

\section{Interaction effect}

The tested genotypes interacted with the water regime and had significant effect on transpiration rate and leaf water content as presented in Tables 1-a and 1-b, respectively. Obtained data clearly indicated that both transpiration rate and leaf water content for all the tested genotypes were decreased gradually and significantly with the reduction in the water regime.

When plants were supplied with adequate water regime $\left(3000 \mathrm{~m}^{3}\right), \mathrm{L} 11$ genotype recorded the highest transpiration rate followed by L38 then L20.While, L350 recorded the lowest transpiration rate. However, under adequate water treatment, L20 had the highest leaf water content, while, Giza 102 and Sakha 53 recorded statistically the lowest leaf water content. Under the moderate water regime, L20 had the highest transpiration rate followed by L38 then L990, while, L350 also had the lowest value in this respect. Concerning leaf water content, L11, L20, L19, L235, L990, L460 and Giza 102 had comparable values and L11 overestimated the rest genotypes in this regard. Under severe drought $\left(1000 \mathrm{~m}^{2}\right.$ of water/fed), L8 had the highest transpiration rate followed by L990 then L11, while, either of Sakha 53 or L460 recorded the lowest transpiration rate values. Nevertheless, under this condition of severe water reduction regime, L11 genotype recorded the highest leaf water content followed by L350, L990, L460, Giza 102 and Sakha 53. These results give an indication about the diversity in transpiration rate among the tested genotypes, as well as, the ability of their leaves to retain water under stress conditions.

\section{Yield attributes}

Effect of water regime levels

Data in Table 2 showed a significant decrease in sunflower plant height, head diameter, number of seeds/head and 1000 seeds weight with the reduction in level of water regime. This was true in both seasons, as well as, their combined results. 

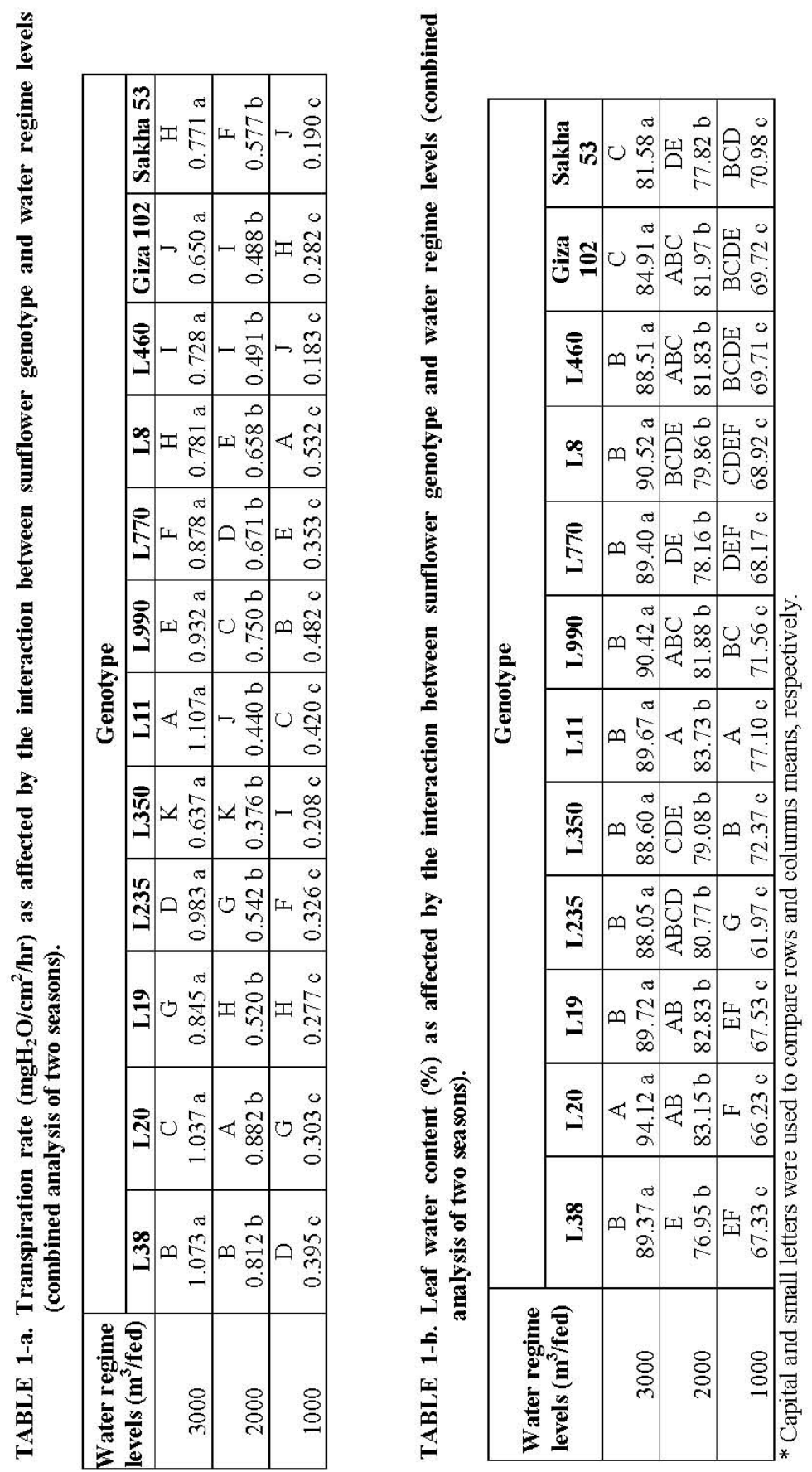

Egypt. J. Agron . 34, No.2 (2012) 
Genotypes differences

Results of both seasons as well as their combination showed high significant differences among the tested genotypes in all yield attributes (Table 2). Data of the combined analysis revealed that L38 and L20 got tallest plants followed by L19 then L235, L990 and L8, while, L350 recorded the shortest one. Again, it is conspicuous that the tallest three genotypes i.e. L38, L20 and L19 were on par in attaining a greatest head diameter, where, heads of L38 were longer than those of the rest genotypes, while, L350 had the smallest heads. Meanwhile, L38, L20, L19, L235, L8 and Giza 102 genotypes were similar in bearing highest number of seeds /head, whereas, L235 had more seeds /head than the rest genotypes. However, L11 recorded the lowest number of seeds/head. Here it can be seen that the genotypes of a wide heads viz L38, L20 and L19 were among those which had more seeds /head. Nevertheless, L38, L990, L460, Giza 102 and Sakha 53 got similar heavy seeds where, L38 surpassed the rest of the genotypes in this respect. On the other side, sunflower genotypes, L20, L19, L350, L11 and L770 were similar in having a lighter seed weight. L350, recorded the lowest seeds weight as compared to the rest of the genotypes. The present results reflect that the superiority of L38 genotype in all yield attributes recorded also showed the highest transpiration rate, regardless of leaf chlorophyll and/or leaf water contents (see Table 1).

\section{Interaction effect}

The interaction between both factors had significant effect on plant height as shown in Table 2-a. Plant height of L38, L20, L19, L235, L990 and L8 was reduced gradually and significantly with each reduction in the water level. But a significant reduction in plant height of L350, L11, L460, Giza 102 and Sakha 53 was induced only with the reduction in the water supply from 3000 to $1000 \mathrm{~m}^{3} / \mathrm{fed}$. Whereas, plant height of L770 was reduced significantly under moderate water regime.

Under the different water regimes, L38, L20 and L19 had a similar plant height. The plants of L20 under different water regimes, as well as, those of L38 under moderate and severe reduction of water regime, were taller than those of the rest of the genotypes. Meanwhile, under the severe water regime L350 had the shortest plant height followed by L11. Moreover, the latter two genotypes were similar in having shorter plants than those of the rest of the tested genotypes under adequate and moderate level of water.

Water regimes interacted with sunflower genotype and had significant effect on number of seeds / head as shown in Table 2-b. Number of seeds /head of L11 was not affected by water regime treatments. Meanwhile, the moderate water regime had insignificant effect on L38 and L20. However they were affected significantly under severe water regime. Severe drought significantly reduced number of seeds /head of L350 as compared with adequate water treatment. Whereas, number of seeds /head of L990, L770, L8, Giza 102 and Sakha 53 was decreased significantly under moderate and severe water restriction. Moreover, any reduction in the water regime caused gradual significant reduction in number of seeds/head of L9 and L235 genotypes. 


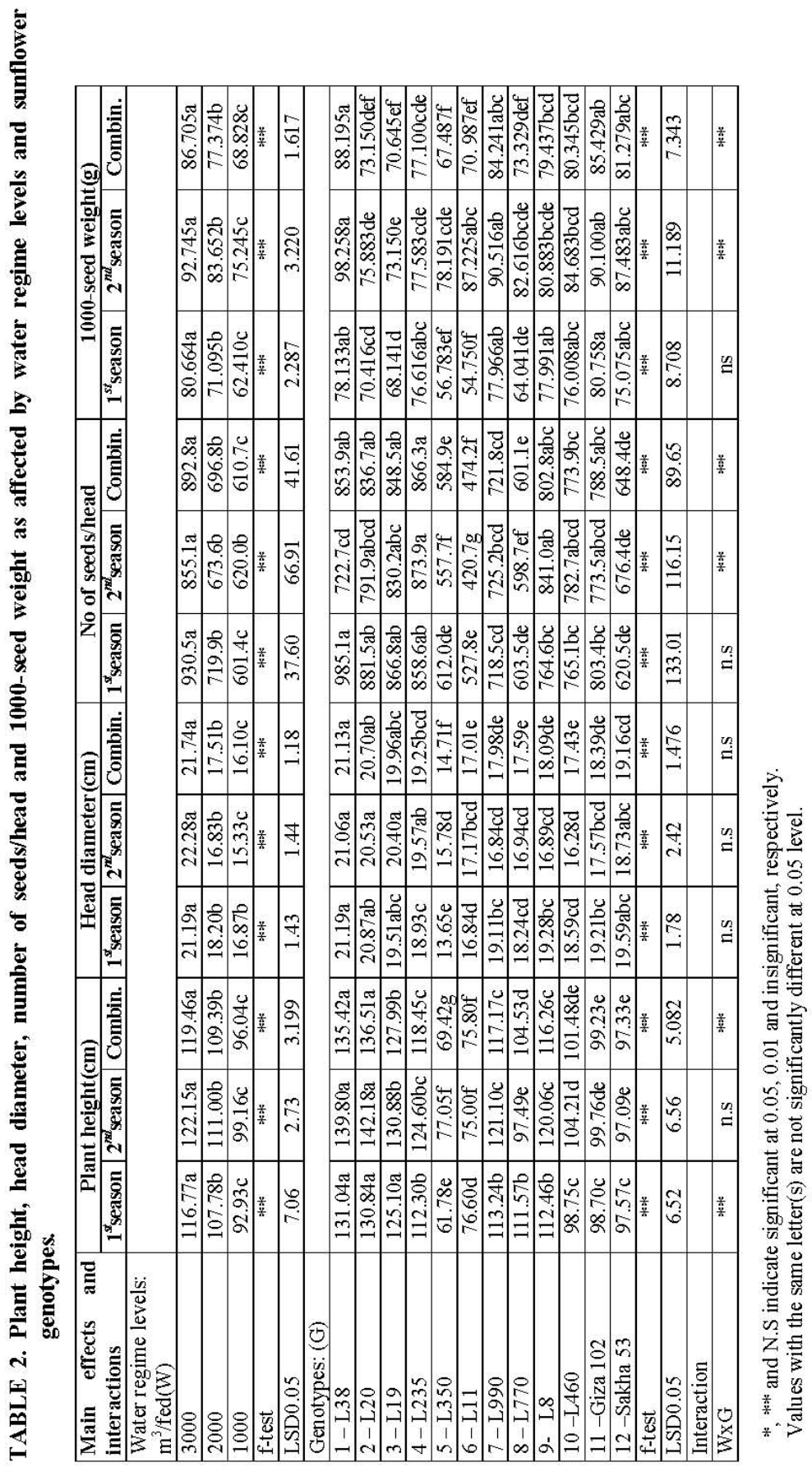

Egypt. J. Agron . 34, No.2 (2012) 
Under adequate water regime, L19, L235, L8 and Giza 102 got similar and high number of seeds /head, where, L19 had higher number of seeds /head than the rest test of the genotypes. However, under the medium level of water supply, L19 and L235, as well as, L38 and L20 were on par in bearing high number of seeds /head, where, the latter three genotypes had a much more number of seeds / head than the rest genotypes. Whereas, under severe water regime, L38 as well as L460 and Giza 102 were nearly similar in number of seeds /head, where, L460 surpassed the rest genotypes in this respect. Here it is of noticeable that $\mathrm{L} 38$ was among the genotypes which had a high number of seeds /head under moderate and severe levels of water regimes.

The level of water supply and sunflower genotypes interacted significantly with regard to 1000 seeds weight as presented in Table 2-c.Thousand seed weight of L38, L19, L235 and L8 was not affected by the water regimes. However, thousand seed weight of L350, L770, L460 and Sakha 53 was decreased significantly with the reduction in the water supply less than $2000 \mathrm{~m}^{3} / \mathrm{fed}$. Also, severe drought (1000 $\mathrm{m}^{3} / \mathrm{fed}$ ) significantly reduced 1000 seed weight of L20 and Sakha 53 as compared with adequate water supply. Whereas, any reduction in the water regime was followed by a significant decrease in 1000-seed weight of L11 and L990 genotypes. When the plants were supplied with the adequate level of water, L990 had the heaviest seed weight followed by L38, L20, L11, L8, L460, Giza 102 and Sakha 53. But, under moderate water regime, L38, L770, Giza 102, L460 and Sakha 53 were comparable in having a heavier seed, where, the later two genotypes surpassed the rest tested genotypes in this respect. However, under severe water regime also L38, Giza 102, Sakha 53 and L990, as well as, L8 and L235 got similar and heavier seed weight. Seed weight of L38 was higher than any of the other genotypes. Here, it is of worth to note that L 38, Giza 102 and Sakha 53 were among the genotypes which had a heavier seed weight under moderate and severe regimes of water.

\section{Seed yield, oil content and oil production}

Effect of water regime levels

As in physiological characters (Table 1), as well as, yield attributes (Table 2), the water regime also had a significant effect on seed yield, oil content and oil yield. This was the same in both seasons and their combination as shown in Table 3. Results of the combined analysis for both seasons exhibited a gradual significant decrease in seed yield and oil content as well as oil yield with each reduction in the level of water.

\section{Genotypes differences}

There were great differences among the tested genotypes in seed yield, oil content and oil production (Table 3). It can be seen that L 38 produced the highest seed yield followed by L20, L235, L990, L8, L460 and Giza 102, then both L19 and Sakha 53. While, L350 and L11 produced similar and lower yield compared with the rest of the genotypes. Accordingly, there were significant differences among the tested genotypes also in oil yield. Results of the combined analysis revealed that L38 produced the highest oil yield followed by L8, L460 and Giza 102, while L11 recorded the lowest oil yield. 

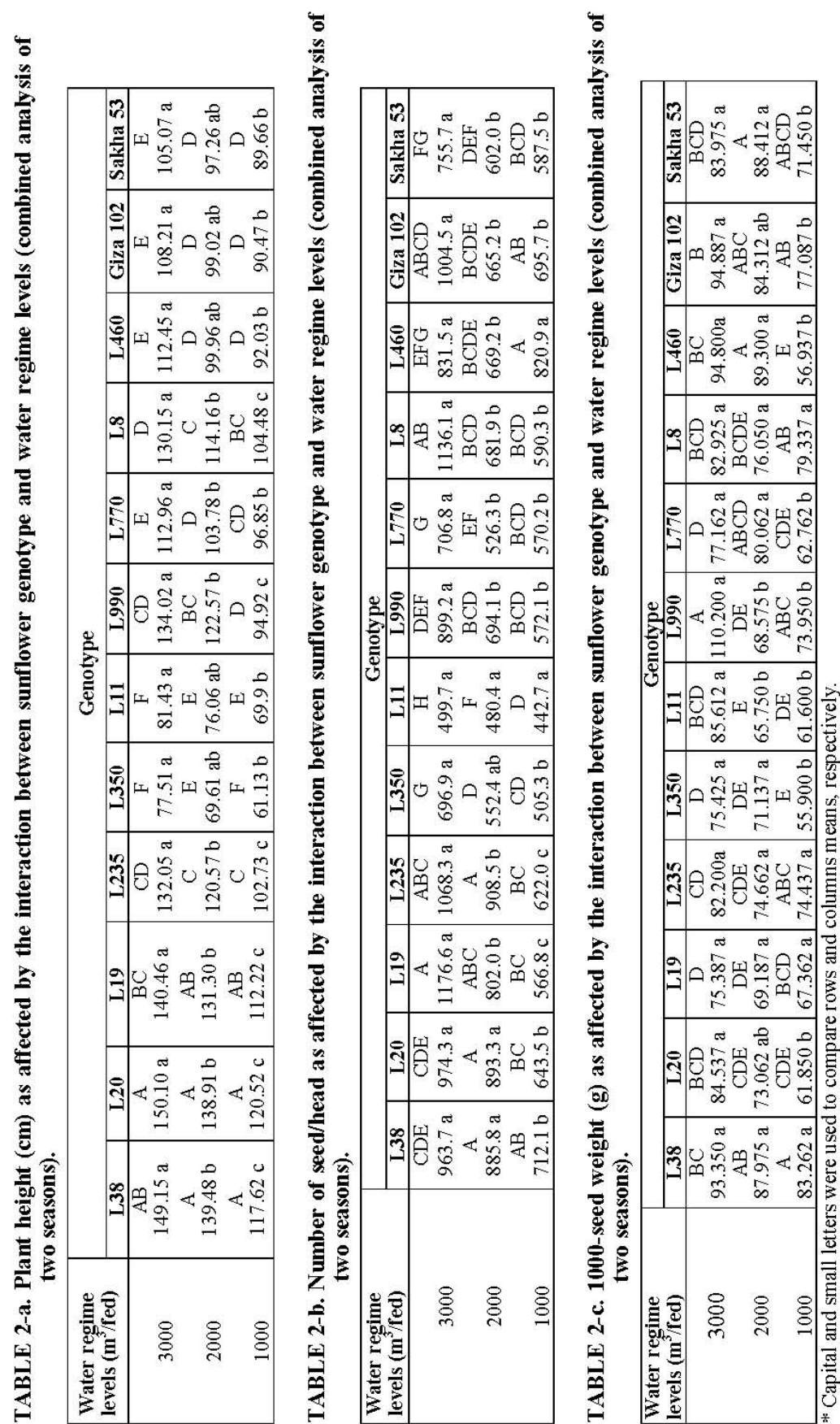

Egypt. J. Agron . 34, No.2 (2012) 
EVALUATION OF SOME SUNFLOWER ...

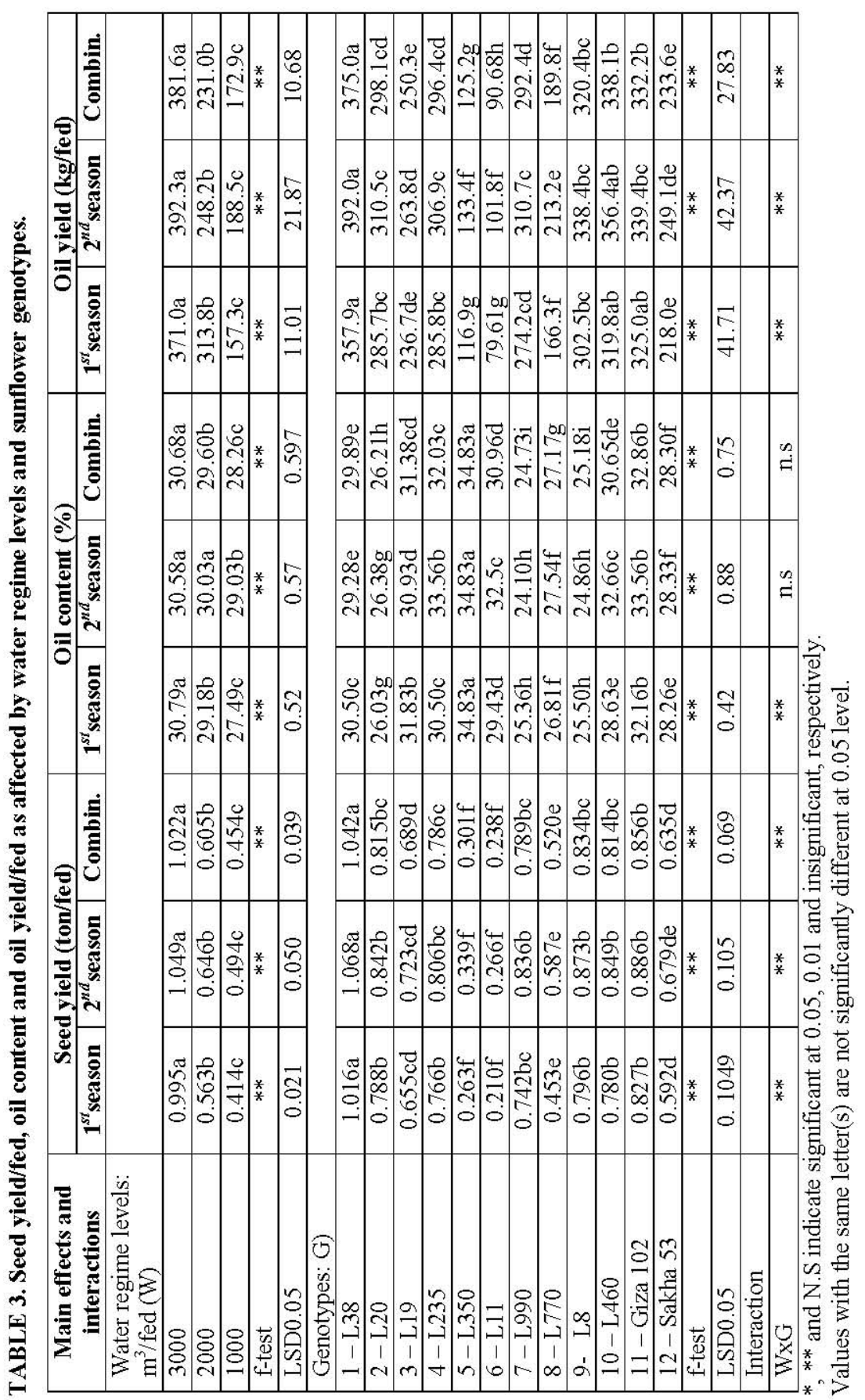

Egypt. J. Agron . 34, No.2 (2012) 


\section{Interaction effect}

The studied factors interacted and significantly affected seed yield as shown in Table 3-a. The reduction in the level of water was followed by a consistent significant decrease in seed yield of L20, L235, L990, L8, L460 and Sakha 53 genotypes. While, seed yield of L 19, L 350, L 11, L 770 and Giza 102 genotypes was decreased significantly only with the reduction in level of water less than 3000 $\mathrm{m}^{3} /$ fed. Seed yield of L38 was decreased significantly only with the reduction in level of water less than $2000 \mathrm{~m}^{3} / \mathrm{fed}$. Under adequate water regime, L990 produced the higher seed yield/fed followed by L38, L8, Giza 102 and Sakha 53 which were on par, while, L11 recorded the lowest seed yield value. But, under both moderate and severe levels of water regime L 38 had the highest seed yield followed by L20, L235, L8, L460 and Giza 102 which were on par, while, L350 and L11 were similar in producing the lowest value of seed yield.

Also, the levels of water supply interacted with sunflower genotypes and had significant effect on oil yield/fed ( Table 3-b). Oil yield of each of L20, L19, L235, L 990, L8, L460, Giza 102 and Sakha 53 was decreased significantly with any reduction in water supply. However, oil yield of L350, L11 and L770 was decreased significantly only with the $1^{\text {st }}$ reduction in water supply. Whereas, L38 was decreased significantly only with the $2^{\text {nd }}$ reduction in water supply.

When plants were provided with adequate water regime, L990, L8, L460 and Giza 102 were similar in securing high oil yield followed by L38, L20, L19 and L235 which were on par, while, L11 had the lowest one. But, when plants received moderate or severe water regime, L 38 produced the highest oil yield followed by L20, L460 and Giza 102 which were on par under both of these levels of water regime, as well as, L460 only under severe water regime, while, both L350 and L11 genotypes were on par in securing the lowest oil yield values under moderate and severe levels of water.

\section{Discussion}

Results regarding chlorophyll index (SPAD value) did not show any significant differences due to the levels of water regime in the second season and the combined analysis. However severe water regime significantly reduced chlorophyll index in the first season. The adverse effect of severe water stress has previously been shown by Kirnak et al. (2001) and Nezami et al. (2008). Chen et al. (1991) have associated the reduction of chlorophyll to the increased electrolyte leakage, while McDonald \& Archbold (1998) have shown that water deficit affect electrolyte leakage. The combined analysis showed that sunflower genotypes significantly varied in chlorophyll values. L235 had the highest leaf chlorophyll value followed by L8. However, L38 and L770 exhibited the lowest chlorophyll values. In this connection, genotypic variation for chlorophyll value was also detected by Raducanu et al. (2008). SPAD index declined progressively with exposure to drought, but the decline was more severe in susceptible genotypes (Silva et al., 2007).

Egypt. J. Agron . 34, No.2 (2012) 
EVALUATION OF SOME SUNFLOWER ...
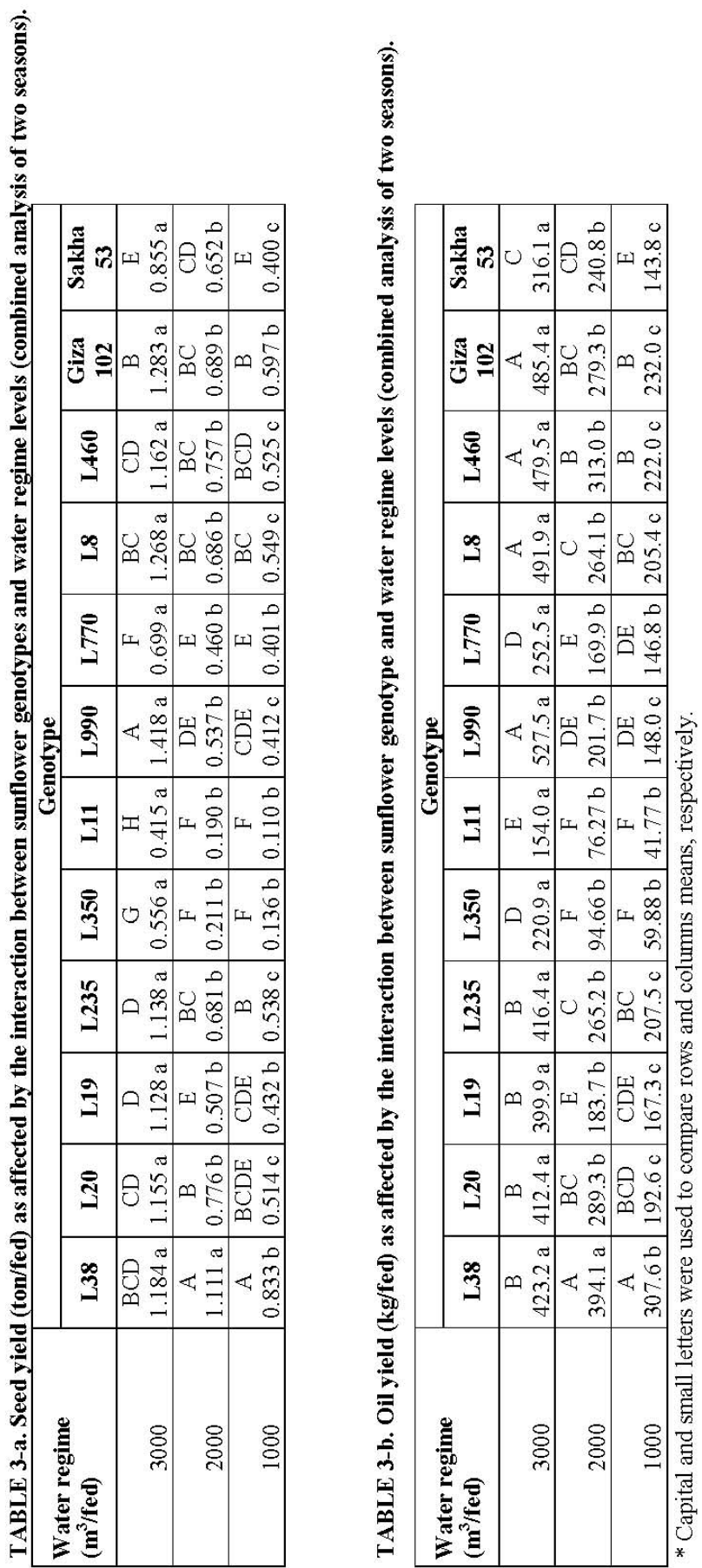

Egypt. J. Agron . 34, No.2 (2012) 
The current study revealed that moderate and severe water regime significantly reduced transpiration rate and leaf water content. Similar finding was also reported by Rahbarian et al. (2011). Under water deficit, the cell membrane is subjected to changes such as increase in penetrability and decrease in sustainability (Blokhina et al., 2003). Microscopic investigations of dehydrated cells revealed damages, including cleavage in the membrane and sedimentation of cytoplasm content (Blackman et al., 1995).

The obtained results revealed significant differences between the studied sunflower genotypes for transpiration rate and leaf water content. This variation among genotypes may be due to the differences in the ability to absorb more water from the soil and the ability to reduce water loss through stomata (Siddique et al., 2000). It may also due to differences in the ability of genotypes to maintain tissue turgor and hence physiological activities (Terzi \& Kadioglue, 2006).

The combined analysis revealed that water stress had significant adverse effect on plant height, head diameter, seeds/head, 1000-seed weight, seed yield, oil content and oil yield. Meantime, a large variation was observed for all these characters. Further results demonstrated that the maximum plant height (119.46 $\mathrm{cm})$, head diameter $(21.74 \mathrm{~cm})$, seeds/head $(892.1), 1000$-seed weight $(86.705 \mathrm{~g})$, seed yield (1.022 ton/fed), oil content $(30.68 \%)$ and oil yield $(381.6 \mathrm{~kg} / \mathrm{fed})$ were attained under adequate water regime, while these characters exhibited the minimum values under severe regime. The adverse effects on sunflower yield contributing characters and oil yield due to moderate and/or severe water regime had previously been shown by Nazarli \& Zardashti (2010).

The reduction of sunflower plant height as response to drought may be either due to decrease of cell elongation resulting from water deficit, which led to a decrease in each cell turgor, cell volume and consequently shorter internodes and stem height (Boyer, 1988) or due to blocking up of xylem and phloem vessels, thus hindering any translocation of water or metabolites (Lovisolo \& Schuber, 1998).

Head diameter was significantly reduced as water stress increased. If head diameter was lower, less seeds would be produced. Comparable results were detected by Nezami et al. (2008) and Nazarli \& Zardashti (2010). A significant genotypic variation was also recorded. However the interactive effects of water regime treatments and sunflower genotypes for head diameter were not significant.

Drought stress had negative effects on 1000-seed weight of all studied genotypes. The high 1000-seed weight, resulting from adequate water regime may probably due to the availability of adequate water and assimilates from source to sink during seed formation and seed ripening stages (Nazarli \& Zardashti, 2010). The lower 1000-seed weight resulting from moderate and/or severe water regime may be due to a lower photosynthate production because of excessive loss of leaves at the flowering stage (Rauf, 2008). Significant variations for head diameter, seeds/head and 1000-seed weight were detected by 
the evaluated sunflower genotypes. Comparable results were also reported by Hakim Khan et al. (2007) and Safavi et al. (2011).

Results have shown that the highest seed yield (1.418 ton/fed) and oil yield $(527.5 \mathrm{~kg} / \mathrm{fed})$ were obtained from sunflower genotype L990 under adequate water regime, while the lowest seed yield ( 0.11 ton/fed) and oil yield 41.77 $\mathrm{kg} / \mathrm{fed}$ ) were attained from L11 under severe water regime. L38 exhibited the highest seed and oil yields under moderate and severe water regime. The superiority of L38 under water deficit may be attributed to some of its components such as seeds/head and 1000-seed weight under such condition. Significant variation existed between sunflower genotypes for seed yield and its contributing characters as well as seed oil yield under adequate and severe water regime (Alahdadi et al., 2011; Mojddam et al., 2011 and Safavi et al., 2011).

Finally, it is concluded that sunflower genotype L990 is recommended to be grow under adequate water regime and L38 under moderate and severe water regime.

Acknowledgment: The authors record their deepest gratitude and thanks to Zagazig University for providing facilities through funding the project titled: Improvement of sunflower for drought tolerance.

\section{References}

A.O.A.C. (1984) "Official Methods of Analysis", of the Association Official Analytical Chemist (AOAC) Washington, D.C.USA pp. 1250-1255.

Abdel-Wahab, A.M., Rhoden, E.E., Bonsi, C.K., El-Ashry, M.A., Megahed, Sh.E., Baumy, T.Y. and El-Said, M.A. (2005) Productivity of some sunflower hybrids grown on newly reclaimed sandy soils as affected by irrigation regime and fertilization. Helia. 28 (42), $167-178$.

Abo Khadrah, S.H., Mohamed, A.A., Gerges, N.R. and Diab, Z.M. (2002) Response of four sunflower hybrids to low nitrogen fertilizer levels and phosphorine biofertilizer. J. Agric. Res. Tanta Univ. 28(1),105-118.

Acko, D.K. (2008) Some economically important properties of sunflower cultivars (Helianthus annuus L.) in the field trials performed at biotechnical faculty. Acta Agric. Slovenica, 91(1), $47-58$.

Alahdadi, I., Oraki, H. and Khajani, F.P. (2011) Effect of water stress on yield and yield components of sunflower hybrids. African J. Biot. 10(34), 6504-6509.

Asbagh, F.T., Moghddam, A.F. and Gorttapeh, A.H. (2009) Influence of water stress and sowing date on sunflower yield and oil percentage. Res. J. Biol. Sci. 4(4), $487-$ 489.

Blackman, S.A., Obendorf, R.L. and Leopold, A.C. (1995) Desiccation tolerance in developing soybean seeds : The role of stress proteins. Plant Physiol. 93, 630-638.

Egypt. J. Agron . 34, No.2 (2012) 
Blokhina, O., Virolinen, E. and Fagerstedt, K.V. (2003) Anti oxidants, oxidative damage and oxygen deprivation stress. Ann. Bot. $91,179-194$.

Boyer, J.S. (1988) Cell enlargement and growth - induced water potentials. Physiol. Plant, 73, $311-316$.

Chen, C., T., Li, C.C. and Kao, C.H. (1991) Senescence of rice leaves XXXI. Changes of chlorophyll, protein and polyamine contents and ethylene production during senescence of a chlorophyll-deficient mutant. J. Plant Growth Regul. 10, 201 - 205.

Duncan, D.B. (1955) Multiple range and multiple F-test. Biometrics, II, 1 - 42.

Esmail, S.E. (2000) Performance of some sunflower cultivars as affected by water irrigation regimes. J. Agric. Sci. Mansoura Univ. 25(2), 675 - 697.

Gosev, N.A. (1960) "Some Methods for Studying Plant Water Relations". Akad.Nauk USSR,Leningrad.

Hakim Khan, Muhammad, S. Shah,R. and Iqbal, N. (2007) Genetic analysis of yield and some yield components in sunflower. Sarhad J. Agric. 23(4), 985 - 990.

Iqbal, N., Ashraf, M.Y. and Ashraf, M. (2005) Influence of water stress and exogenous glycinebetaine on sunflower achene weight and oil percentage. Int. J. Environ. Sci. Techn. 2(2), $155-160$.

Kazi, B.R., Oad, F.C., Jamro, G.H., Jamali, L.A. and Oad, N.L. (2002) Effect of water stress on the growth, yield and oil content of sunflower. Pakistan J. Appl. Sci. 2 (5), $550-552$.

Kirnak, H., Kaya, C., Tas, I. and Higgs, D. (2001) The influence of water deficit on vegetative growth, physiology, fruit yield and quality in eggplants. Bulgarian J. Plant Physiol. 27 (3-4), $34-46$.

Lorens, G.F., Bennet, J.M. and Loggale, L.B. (1987) Differences in drought resistance between two corn hybrids. II. Component analysis and growth rates. Agron. J. 79, 808 813.

Lovisolo, C. and Schuber, A. (1998) Effects of water stress on vessel size xylem hydraulic conductivity in Vitis vinifera L. Journal of Exp. Botany, 49(321), 693 - 700.

McDonald, S. and Archbold, D. (1998) Membrane competence among and within Fragaria species varies in response to dehydration stress. J. Am. Soc. Hort. Sci. 123 (5), $808-813$.

Migahid, A.M. and Amer, F.A. (1952) Three types of transpiration of snap bean. Agron. J. 44, $562-568$.

Mojaddam, M., Lack, S. and Shokuhfar, A. (2011) Effect of water stress and different levels of nitrogen on yield and yield components and WUE of sunflower hybrid Iroflor . Advances in Environmental Biology,5(10), 3410 - 3417. 
Nazarli, H. and Zardashti, M.R. (2010) The effect of drought stress and super absorbent polymer (A200) on agronomical traits of sunflower (Helianthus annuus L.) under field condition. Cercetari Agronomice in Moldova Vol. XLIII, (3) 143, pp. 5 - 14.

Nezami, A., Khazaei, H.R., Boroumand Rezazadeh, Z. and Hosseini, A. (2008) Effects of drought stress and defoliation on sunflower (Helianthus annuus) in controlled conditions. Desert, 12, 99 - 104.

Raducanu, F., Petcu, E. and Moraru, I. (2008) Genetic variability of some Romanian sunflower genotypes under in vitro stress induced by Phomopsis helianthi filtrate. Romanian Agric. Res. Number 17 - 18, 9 - 18.

Rahbarian, R., Khavari-Negad, R., Ganjeali, A., Bagheri, A. and Najafi, F. (2011) Drought stress effects on photosynthesis, chlorophyll fluorescence and water relations in tolerant and susceptible chickpea (Cicer arientinum L.) genotypes. Acta Biologica Cracoviensia Series Botanica, 53(1), 47 - 56.

Rauf, S. (2008) Breeding sunflower (Helianthus annuus L.) for drought tolerance. Communications in Biometry and Crop Science, 3 (1) 29-44.

Rauf, S. and Sadaqat, H.A. (2007) Sunflower germplasm evaluation for drought tolerance. Communications in Biometry and Crop Science, 2(1), 8 - 16.

Rauf, S. and Sadaqat, H.A. (2008) Identification of physiological traits and genotypes combined to high achene yield in sunflower (Helianthus annuus L.) under contrasting water regimes. Aust. J. Crop. Sci. 1(1), 23 - 30.

Rauf, S., Sadaqat, H.A. and Khan, I.A. (2008) Effect of moisture regimes on combining ability variation of seedling traits in sunflower (Helianthus annuus L.). Canadian J. Plant Sci. 88, 323 - 329.

Reddy, G.K.M., Dangi, K.S., Kumar, S.S. and Reddy, A.V. (2003) Effect of moisture stress on seed yield and quality in sunflower (Helianthus annuus L.). J. Oil Seeds Res. $\mathbf{2 0}(2), 282-283$.

Safavi, S.M., Safavi, A.S. and Safavi, S.A. (2011) Heritability and Genetic gain of some morphological traits in sunflower (Helianthus annuus L.) under water stress conditions. American J. Scientific Res. 19, 27 - 31.

Sarhan, A.A. (1995) Varietal response to plant spacing in sunflower under sandy soil conditions. Zagazig J. Agric. Res. 22(1),11 - 30 .

Siddique, M.R.B., Hamid, A. and Islam, M.S. (2000) Drought stress effects on water relation of wheat. Bot. Bull. Acad. Sin. 41(1), 35-39.

Silva, M.A., Jifon, J.L., da Silva, J.A.G. and Sharma, V. (2007) Use of physiological parameters as fast tools to screen for drought tolerance in sugarcane. Braz. J. Plant Physiol. 19(3),193 - 201.

Sharief, A.E., El-Kalla, S.E., El-Kassaby, A.T., Sultan, M.S. and El-Bossaty, Nagwa A.A. (2003) Response of some short duration cultivars of soybean and sunflower to intensive cropping. Scientific J. King Faisal Univ. 4(1), 95 - 104.

Egypt. J. Agron. 34, No.2 (2012) 
Steel, R.G. D. and Torri, J.H. (1980) "Principles and Procedures of Statistics". McGraw-Hill Book Co., New York, USA.

Terzi, R. and Kadioglu, A. (2006) Drought stress tolerance and the antioxidant enzyme system in Ctenanthe setosa. Acta Biol. Cracov Bot. 48, 89 - 96.

Turner, N.C. (1981) Techniques and experimental approaches for the measurement of plant water status. Plant and Soil,58, $339-366$.

Yasein, M.A.T. (2010) Some agronomic factors affecting productivity and quality of sunflower crop (Helianthus annuus L.). Ph.D. Thesis, Agron. Dept., Fac. Agric., Zagazig Univ., Egypt.

(Received 14/6/2012;

accepted 21/10/2012) 


\section{تقييم بعض هجن عباد الشمس تحت ظروف الجفاف فى الأراضى الرملية المستصلحة حليثاد

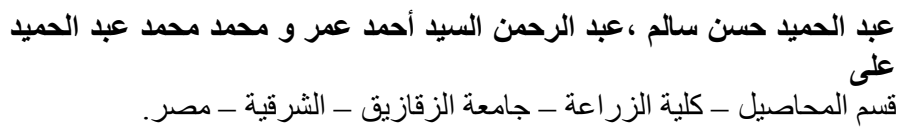

أجريت تجربتان حقليتان فى المزرعة التجريبية التابعة لكلية الزراعة - جامعة

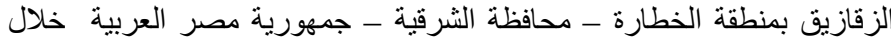

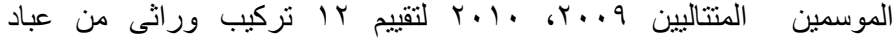

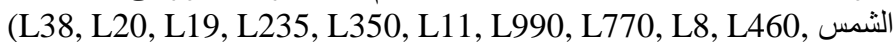
تحت ثلاثة مستويات من الامداد المائى لنظام

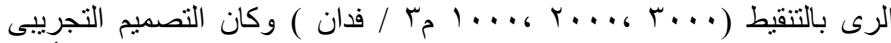

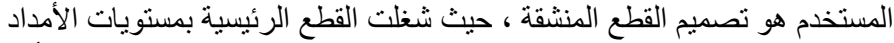

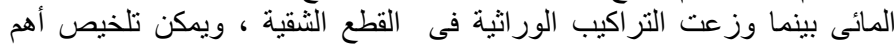

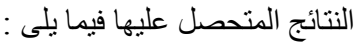

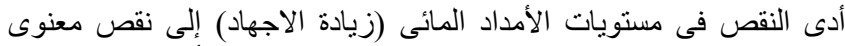

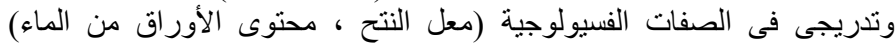

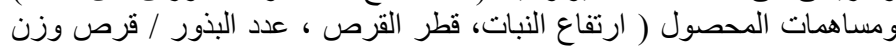

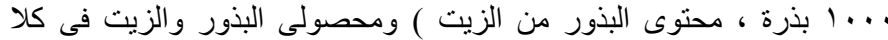

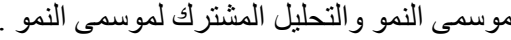

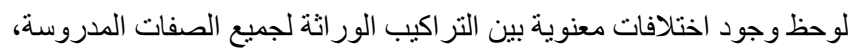

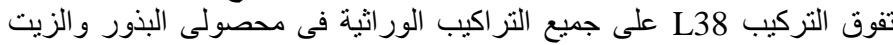

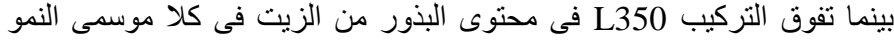

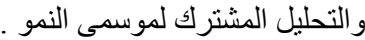

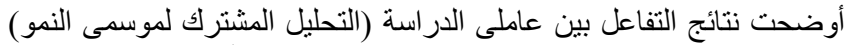

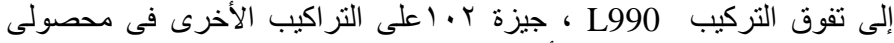

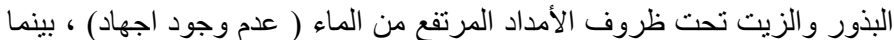

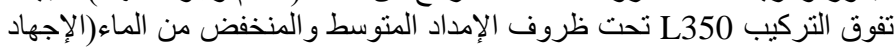
المتوسط و المرتفع). 